\title{
Identidades naufragadas: o impacto das organizações na (re)construção do universo simbólico dos ribeirinhos de Salto Santiago
}

\author{
Shipwrecked identities: the impact of organizations in the symbolic universe \\ (re)construction of riparian people from Salto Santiago
}

Adriana Vinholi Rampazo ${ }^{1}$

Elisa Yoshie Ichikawa ${ }^{2}$

\begin{abstract}
Resumo
Para a construção da Usina Hidrelétrica Salto Santiago, localizada na região centro-sul do Paraná na década de 1970 , foi necessário deslocar os ribeirinhos que ali viviam para dar lugar ao seu reservatório. Este artigo tem por objetivo analisar o papel de diferentes organizações na (re)construção da identidade dos ribeirinhos deslocados compulsoriamente de seus territórios para dar lugar a esse reservatório. Para tanto, leva-se em conta que a identidade é construída e reconstruída dentro do espaço social a partir do desejo do Outro que, ao ser reconhecido pelo sujeito como legítimo, internaliza suas práticas, ações e visão de mundo e, portanto, seu habitus. Em termos metodológicos, foi conduzido um estudo qualitativo que envolveu levantamento documental e entrevistas semiestruturadas utilizando as técnicas da história oral com os ribeirinhos e com os representantes das principais organizações presentes hoje no local. Os dados coletados foram interpretados a partir das regras da hermenêutica filosófica de Gadamer, interligando o individual ao geral, e vice-versa, assim como o objetivo com o subjetivo. Por fim, em termos de conclusões, com base na história contada pelos ribeirinhos e pelos representantes das organizações pesquisadas, mostra-se como se deu a (re)construção das identidades dos ribeirinhos naquele espaço. Assim, foi possível constatar como a construção da Usina Salto Santiago e o consequente deslocamento de parte dos ribeirinhos produziu, devido à entrada de novas organizações naquele território, modificações em suas identidades.
\end{abstract}

Palavras-chave: Identidade. Simbolismo. Organizações. Usina hidrelétrica. Deslocamento compulsório.

\begin{abstract}
For constructing the Salto Santiago Hydroelectric Power Plant, located at the central-southern state of Parana, Brazil, in the 1970s, there was a need to displace the riparian people who lived there to make way for the reservoir. This paper aims to analyze the role of different organizations in the identity (re)construction of the riparian people compulsorily displaced from their territories to make way for this reservoir. For this, one takes into account that identity is constructed and reconstructed within the social space through the Other's desire which, being acknowledged as legitimate by the subject, internalizes his practices, actions, and worldview and, therefore, his habitus. In methodological terms, one conducted a qualitative study involving documentary survey and semi-structured interviews using the oral history techniques with the riparian people and representatives of key organizations currently found on site. The collected data
\end{abstract}

Artigo submetido em 17 de julho de 2012 e aceito para publicação em 07 de março de 2013.

1 Doutoranda em Administração da Universidade de São Paulo/FEA-USP; Professora da Universidade Estadual do Paraná UNESPAR. Endereço: Caixa Postal 8031, CEP 86010-970, Londrina-PR, Brasil. E-mail: arampazo@usp.br

2 Doutora em Engenharia de Produção pela Universidade Federal de Santa Catarina - UFSC. Estágio pós-doutoral no CEPEAD/UFMG - Centro de Pós-Graduação e Pesquisas em Administração da Universidade Federal de Minas Gerais; Professora da Universidade Estadual de Maringá. Endereço: Avenida Colombo, 5790 -UEM/CSA/DAD, CEP 86020-900, Maringá-PR, Brasil. E-mail: eyichikawa@uem.br 
were interpreted through the rules of Gadamer's philosophical hermeneutics, interconnecting the individual to the general perspective, and vice-versa, as well as the objective to the subjective perspective. Finally, in terms of conclusions, based on the story told by the riparian people and representatives of the organizations under study, one shows how the identity (re)construction of riparian people took place at that space. Thus, it was possible to find out how the Salto Santiago Power Plant construction and the resultant displacement of riparian people produced, due to entry of new organizations in that territory, changes in their identities.

Keywords: Identity. Symbolism. Organizations. Hydroelectric power plant. Compulsory displacement.

\section{Introdução}

As usinas hidrelétricas são incríveis obras de engenharia. Com seu surgimento, no século XIX, o ser humano provou que é capaz de dominar a força da natureza para gerar energia em grande escala. No entanto, como objeto construído e de dimensões relevantes, as usinas hidrelétricas, muitas vezes, são fatores de desestruturação social.

Estudos nas mais diversas áreas (REBOUÇAS, 2000a; 2000b; REIS, FADIGAS e CARVALHO, 2005; ESTRELA, 2006; KARPINSKI, 2007; SOARES, FROEHLICH e MARQUES, 2007) discutem o impacto negativo das hidrelétricas sobre o território, incluindo mudanças na geografia, nas relações sociais, na economia local e, como resultado disso, alterações no modo de vida das pessoas e nas suas identidades. $\mathrm{O}$ reservatório de uma usina, que costuma ocupar centenas de quilômetros, inunda uma grande extensão de terra produtiva, obrigando os ribeirinhos a saírem de suas casas, sendo muitas vezes compulsoriamente e a longas distâncias. Aqueles que conseguem ficar nas margens do rio, transformado agora em um grande reservatório, sofrem com as modificações que ocorrem no local - como a redução da pesca, alterações na qualidade da água, desaparecimento da fauna e da flora nativas, mudanças nas características do solo - e, principalmente, com a perda da rede de relações historicamente construída.

Muitos desses problemas não são apenas econômicos, e qualquer valor oferecido pelos donos das usinas como compensação pela inundação das terras dos ribeirinhos, por maior que pareça, nem sempre atenua as perdas que eles tiveram. Não tem como avaliar a perda dos laços de amizade, a relação de confiança com os vizinhos e com os comerciantes locais, a identificação com o território e o reconhecimento entre eles, que construía a sua identidade. O deslocamento e a inundação das terras "[...] sempre resulta na perda de importantes referenciais que regiam a vida no rio [...]”, afirma Rebouças (2000b, p.28).

Ao se deparar com mudanças objetivas em suas vidas, suas estruturas de percepção começam a mudar, principalmente porque a desestruturação do espaço nas margens das hidrelétricas, não raro, traz riscos de empobrecimento devido à disputa social pela apropriação do território (REBOUÇAS, 2000a). Isso permite a entrada de novas organizações, algumas orientadas por uma ideologia de "esquerda", que contestam o poder dominante, e outras que promovem o ajustamento dos ribeirinhos a ele. Essas organizações, em um processo de luta por reconhecimento e legitimação, travam uma batalha para impor seu poder simbólico naquele espaço e incorporação de seus habitus. Como escreve Bourdieu (2004b, p.57), "[...] os dominados são dominados também em seus cérebros". Suas práticas, modos de ver a vida, estratégias não são conscientes, mas produto do sentido do jogo. Sentido do jogo tacitamente incorporado pelos agentes. Mas como o habitus se instala nos indivíduos formando seu modo de ver o mundo?

Segundo Bourdieu (1996b), a identidade é construída no espaço social a partir da dupla-estruturação de elementos objetivos e subjetivos. Os elementos objetivos, dos objetos, ao mesmo tempo em que definem a posição de um dado agente no espaço social, dependem dos elementos subjetivos, das estruturas mentais desses agentes na percepção daquilo que é objetivo. Os elementos objetivos e subjetivos, portanto, operam dentro da dinâmica do reconhecimento e desconhecimento, forçando a incorporação de um determinado habitus. 
Para compreender o funcionamento desse processo, tomamos emprestado de Lacan (1999) a teoria de sujeito como desejo do Outro e não como satisfação dos seus próprios desejos. Para Lacan (1999), o sujeito vive em estado de alienação, assujeitado pelo desejo do Outro, que preenche o seu inconsciente através do discurso (a fala do Outro). É que, para se tornar sujeito, o indivíduo se assujeita ao Outro. Portanto, em busca de reconhecimento, faz uma escolha forçada, a escolha da alienação, que "envolve 'o próprio' desaparecimento" (FINK, 1998, p.74).

Desta forma, a identidade, para este estudo, não é aquela considerada como a visão do sujeito sobre si mesmo, visto que partimos do pressuposto de que aquilo que ele pensa sobre si mesmo não exprime sua identidade, mas somente a "fala do Eu", que, segundo Lacan (1999), é um discurso consciente e intencional. Identidade, aqui, é definida como construída e reconstruída dentro do espaço social a partir do desejo do Outro (LACAN, 1999; 2009) que, ao ser reconhecido pelo indivíduo como legítimo, internaliza suas práticas, ações e visão de mundo e, portanto, seu habitus (BOURDIEU, 2004a; 2004b; 2003a; 2003b; 1996a; 1996b). É neste contexto teórico, portanto, que este artigo se insere.

Assim, este artigo tem o objetivo de compreender o papel de diferentes organizações na (re)construção da identidade dos ribeirinhos deslocados compulsoriamente de seus territórios para dar lugar ao reservatório da Usina Hidrelétrica Salto Santiago. Essa Usina foi construída na década de 1970, na mesorregião centro-sul do Estado do Paraná. Salto Santiago está entre as maiores hidrelétricas da região e para a formação de seu reservatório foi necessário deslocar uma parcela expressiva dos ribeirinhos dos municípios ao seu redor. Os que conseguiram ficar se defrontaram com uma porção tão pequena de terra que elas não são mais economicamente viáveis (CONDETEC, 2004). Esta situação também fez aumentarem os conflitos para a posse da terra na região, lembra Lopes (2002).

Para alcançar o objetivo do trabalho, foi realizado um estudo qualitativo que envolveu o levantamento documental e entrevistas com os ribeirinhos e com os representantes das principais organizações presentes hoje no local. Nas entrevistas, foram utilizadas as técnicas de história oral a fim de se recuperar aquilo que foi vivido pelos sujeitos de pesquisa. Para a interpretação dos dados coletados, foi utilizada a regra da hermenêutica filosófica de Gadamer $(2008 ; 2007)$, que permite o desvelamento da palavra escrita e falada a partir da estranheza e a familiaridade com o assunto, conforme a herança histórica e tradição de cada um.

Como se pode perceber por esta Introdução, na realização desta pesquisa fomos levadas a ser uma espécie de bricoleurs, pois, aos termos contato com nosso objeto de pesquisa, notamos o quanto ele era variável e imprevisto, e um olhar único não abarcaria toda a complexidade do que estávamos procurando compreender. Kincheloe (2005a, p.319) destaca que um objeto de pesquisa "não pode ser descrito como uma entidade encapsulada", e foi com esse olhar que procuramos compreender o fenômeno em questão.

O pesquisador bricoleur utiliza uma diversidade de perspectivas para contextualizar o objeto de pesquisa. De acordo com Kincheloe (2005b, p. 344), "esta multiperspectiva é realçada pela hermenêutica e pelas interpretações que ocorrem no círculo hermenêutico - os hermeneutas se referem frequentemente a esta dinâmica como a fusão dos horizontes". Isso porque, na hermenêutica, segundo Kincheloe (2005b), o contexto social participa do processo de interpretação. Portanto, é com esse suporte que, neste trabalho, optamos por trabalhar em bases epistemológicas aparentemente tão diferentes, como Bourdieu e Lacan, na teoria, e Gadamer no método, mas foi essa bricolage que nos permitiu chegar às interpretações realizadas para este artigo.

O artigo está estruturado da seguinte forma: inicialmente será apresentado o conceito de identidade aqui utilizado, tendo por base a teoria sociológica de Bourdieu (2004a; 2004b; 2003a; 2003b; 1996a; 1996b) e psicanalítica de Lacan (1999; 2009); em seguida, serão apresentados estudos em diferentes áreas que focam os impactos causados pelas usinas hidrelétricas aos ribeirinhos; o percurso metodológico é descrito na quarta parte deste estudo; em seguida, são discutidos os dados da pesquisa a partir da descrição de quem são (ou foram) os ribeirinhos, do papel das organizações no local após a construção da hidrelétrica e, finalmente, como essas organizações aturaram/atuam na (re)construção da identidade dos ribeirinhos. Por último, fazemos nossas considerações finais. 


\section{A Construção da Identidade}

Falar de identidade implica, necessariamente, falar do processo de socialização. Bourdieu (2004a) afirma que a socialização se dá através da incorporação de disposições duradouras que faz o agente enxergar as normas, as práticas, os saberes do campo em que está inserido como normal. As disposições duradouras, para Bourdieu (2003a; 2003b), são o habitus. Assim, condições semelhantes de vida produzem modos de pensar, gostos e estilos de vida parecidos. Habitus específicos, portanto, engendram uma mesma lógica em todos que a ele estão submetidos, forçando-os às mesmas práticas e definindo suas racionalidades.

Assim, para Bourdieu (2004a), os agentes são resultados de habitus específicos, estruturados pelas formas inconscientes de percepção e ação disseminadas e interiorizadas durante sua vida. Ao nascer numa família, numa dada posição de classe, a pessoa é socializada para reproduzir espontaneamente as relações ali presentes, resultado das lutas anteriores de representação no espaço social.

Em cada campo existe um poder que o rege, "num dado momento" (BOURDIEU, 2004a, p.134). E esse poder, de acordo com Bourdieu (2004a, p.135), é "a forma percebida e reconhecida como legítima das diferentes espécies de capital" que permite a um agente acumular "prestígio, reputação, fama, etc.". Trata-se de um poder invisível - poder simbólico, na concepção de Bourdieu (2004a) -, que opera sem ser notado, e que, ao mesmo tempo, conta com a cumplicidade dos que a ele estão sujeitos, aumentando a sua legitimidade e, portanto, a sua disseminação. Desta forma, o poder simbólico não necessita da força física ou econômica para funcionar, mas sim, da legitimidade. O poder simbólico impõe ao grupo "princípios de visão e de divisão comuns, portanto, uma visão única de sua identidade, e uma visão idêntica da sua unidade" (BOURDIEU, 2004a, p.117).

O agente, por meio do reconhecimento, internaliza e incorpora as relações sociais e reproduz suas práticas com o intuito de acumular prestígio em um determinado campo. Estratégia, portanto. Não a estratégia como sinônimo de escolha intencional e consciente e nem, tampouco, uma ação inconsciente. Para Bourdieu (2004b, p.81), a estratégia "[...] é produto do senso prático como sentido do jogo, de um jogo social particular, historicamente definido, que se adquire desde a infância, participando das atividades sociais [...]". Mesmo nas sociedades em que a escolha do cônjuge não é definida por seus pais como forma de alianças de interesses, os casais normalmente se formam a partir da afinidade de habitus. É comum, portanto, casamentos entre pessoas que estudaram na mesma universidade, que frequentam o mesmo clube ou moram no mesmo bairro. Assim, o amor, para Bourdieu (2004b), também pode ser descrito como o "amor fati", ou seja, como uma forma de amor em que o parceiro ama no outro aquilo que ele reconhece como suas próprias características, vislumbrando seu próprio destino social.

Goffman (1999) pensa de forma semelhante a Bourdieu (2004b), pois, para ele, o sujeito não tem total consciência de suas ações, que estão subordinadas à tradição do seu grupo. Mesmo que algumas vezes aparente estar sendo consciente nas suas ações, nada mais é do que ajuste às demandas do seu grupo. Assim, Goffman (1999, p.15) afirma que: "ocasionalmente, expressar-se-á intencional e conscientemente de determinada forma, mas, principalmente, porque a tradição de seu grupo ou posição social requer este tipo de expressão, e não por causa de qualquer resposta particular (que não a de vaga aceitação ou aprovação), que provavelmente seja despertada naqueles que foram impressionados pela expressão".

Aqui nos parece oportuno tratar da questão de espacialidade, pois, segundo Pimentel e Carrieri (2011, p.7), “[...] é no e pelo espaço que se dão as lutas pelo poder simbólico". Santos (1977) defende que o espaço - e seus significados, história e condições objetivas - não tem papel neutro, pois condiciona a formação social. Seguindo essa linha de pensamento, Pimentel e Carrieri (2011) defendem a incorporação da espacialidade nos estudos sobre identidade. Assim, tendo como referência os estudos dos geógrafos Milton Santos, John A. Agnew e Edward Soja, definem espacialidade como "[...] aquilo que se manifesta fisicamente no espaço, por meio de objetos e sistemas de ação e, simbolicamente, por meio de sua representação mental [...]" (PIMENTEL e CARRIERI, 2011, p.17). A maior contribuição da proposta de Pimentel e Carrieri (2011) é que eles buscam ampliar o conceito de identidade nos estudos organizacionais brasileiros relacionando a objetividade com a subjetividade em um determinado espaço. 
No espaço social, há elementos objetivos e subjetivos que formam a identidade. Do lado objetivo temos, por exemplo, a bandeira e a língua. No entanto, segundo Bourdieu (1996b), não podemos nos esquecer de que esses objetos acabam por serem signos representativos de um poder. Esses signos distintivos, resultados de lutas anteriores, podem ser percebidos no espaço social a partir de uma dupla estruturação: objetiva, o "mundo dos objetos"; e subjetiva, das "estruturas mentais" (BOURDIEU, 2004a; 2004b). "As primeiras instituem o mundo inteligível, que só é inteligível porque pensado a partir das segundas", destaca ThiryCherques (2006, p. 31). Em nome da dominação legítima, disputas simbólicas são travadas no interior do espaço social, permitindo ao dominador impor sua visão de mundo aos dominados.

Nos estudos de Bourdieu (2004b) fica evidente que dominantes e dominados reconhecem suas posições. Os dominados podem preferir seu próprio estilo de vida, mas não deixam de reconhecer a superioridade dos dominantes. Tanto é assim que os dominados, quando em contato com alguém que mesmo ocupando posições superiores na hierarquia do campo usa estratégias de condescendência - negando a distância simbólica que os separam (mesmo que elas não deixem de existir) -, reconhecem a distância nas suas falas: "ele é uma pessoa simples, para um duque" (BOURDIEU, 2004b, p.154). O dominante, então, não obtém reconhecimento apenas de seus pares, mas também dos dominados.

Em um determinado espaço social, escreve Bourdieu (1996a), coexistem diferentes espaços simbólicos. Assim, o espaço social não é homogêneo, visto que ele é construído a partir de dois princípios de diferenciação em sociedades avançadas, o capital econômico e o capital cultural. Desta forma, a partir das categorias sociais de percepção, os agentes são classificados conforme suas práticas e bens que possuem. Um grande empresário possui mais capital econômico que um professor universitário, que, por sua vez, possui mais capital cultural que o empresário. Cada classe de posições, afirma Bourdieu (1996a), possui um determinado habitus, que estrutura as posições diferenciadas no mundo social.

Os habitus são princípios geradores de práticas distintas e distintivas - o que o operário come, e sobretudo sua maneira de comer, o esporte que pratica e sua maneira de praticá-lo, suas opiniões políticas e sua maneira de expressá-las diferem sistematicamente do consumo ou das atividades correspondentes do empresário industrial; mas são também esquemas classificatórios, princípios de classificação, princípios de visão e de divisão e gostos diferentes. Eles estabelecem as diferenças entre o que é bom e mau, entre o bem e o mal, entre o que é distinto e o que é vulgar etc., mas elas não são as mesmas (BOURDIEU, 1996a, p.22).

O ser humano tenta constantemente ser diferente, afirma Bourdieu (1996a). Ao mesmo tempo, para ser diferente ele precisa ser reconhecido por alguém como um semelhante. As marcas de sua distinção, portanto, devem estar inscritas no espaço em questão (BOURDIEU, 1996a). Não adianta alguém tocar piano se ninguém reconhece sua prática. Desta forma, para Bourdieu (2004b), essas marcas distintivas, ao serem percebidas por agentes capazes de distingui-las, funcionam como signos distintivos, positivos ou negativos, como formas de reconhecimento e desconhecimento. É por isso que, conforme escreve Bourdieu (2004b, p.160), "o espaço social tende a funcionar como um espaço simbólico, um espaço de estilos de vida e de grupos de estatuto, caracterizados por diferentes estilos de vida".

Quando se constata que o habitus se instala nos agentes tacitamente formando seu modo de ver o mundo, torna-se necessário tentar compreender como isso acontece no inconsciente, uma vez que, chama a atenção Misoczky (2003), trabalhar com os conceitos de Bourdieu pressupõe a interação entre o objetivo e o subjetivo.

Dessa forma, complementando os estudos de Bourdieu, a teoria lacaniana de sujeito como desejo do Outro e não como satisfação dos seus próprios desejos pode nos revelar como o discurso do Outro entra no sujeito. A teoria lacaniana, segundo Steinmetz (2006, p. 453), complementa os conceitos de poder simbólico e habitus desenvolvidas por Bourdieu, uma vez que permite a redução do problema da incorporação automática do social ao individual, "[...] como se fosse uma simples correia transportadora". 
Bourdieu nunca citou Lacan diretamente em seus estudos. No entanto, concordamos com Steinmetz (2006) quando ele diz que há uma aproximação entre as ideias desses dois pensadores. Primeiro, porque a teoria de Bourdieu se concentra na internalização e incorporação das relações sociais e, portanto, relaciona-se com a preocupação lacaniana do corpo simbólico, marcado pelo desejo do Outro. Segundo, porque Bourdieu trabalha os mecanismos subjetivos por meio dos quais opera a imposição simbólica de reconhecimento e desconhecimento, havendo uma aproximação com o conceito de escolha forçada de Lacan, pelo qual o indivíduo passa para se tornar sujeito.

Para Lacan (1999), o sujeito está em falta e, portanto, vive em constante estado de alienação, sendo assujeitado pelo desejo do Outro. Apesar de em nenhum momento falar em identidade - principalmente porque na psicanálise, de acordo com Godoi (2005, p.51), há "uma visão de sujeito enquanto assujeitado, submetido ao inconsciente; sujeito constituído a partir do outro" - Lacan (1999) discorre constantemente em sua obra sobre a significação que o discurso do Outro impõe ao sujeito, de forma que este esteja impregnado pelo desejo do Outro. Para Lacan (1999), o sujeito é uma significação, alienado pelo significado que o Outro lhe impõe. O sujeito, neste caso, não passa de um ser onde o discurso e desejo do Outro está internalizado. Quando desejamos nos tornar pessoas melhores, por exemplo, podemos ter um desejo que não é nosso, mas sim do Outro, afirma Fink (1998). O que tentamos, portanto, é alcançar o ideal das outras pessoas, o eu-ideal, que sempre discorda da nossa realidade (LACAN, 1999).

A pergunta que se faz agora é: como este Outro entrou em nós? Como ele se insinua dentro de nós, fazendo com que percamos o controle sobre o que estamos falando e, pior, desejando? De acordo com Lacan (1999), é pelo discurso - o já dito - que o Outro preenche o inconsciente humano, fazendo com que todo desejo esteja definido antes mesmo do seu nascimento. Lacan (1999) explica que existem dois tipos de discurso: "a fala do eu" e "a fala do Outro" e que ambas estão relacionadas, formando o sujeito. Devido a isto, o ser é um sujeito dividido entre o consciente e o inconsciente, entre "a fala do eu" e "a fala do Outro". O primeiro, "a fala do eu", relaciona-se àquilo que o sujeito pensa conscientemente; é, portanto, como ele acredita ser (mas, que na verdade, não é, pois podemos ser tão ou mais ignorantes quanto as outras pessoas com relação ao que somos). Este tipo de discurso surge no Self (Eu) e, devido a isso, é consciente e intencional. No segundo caso, "a fala do Outro" surge no inconsciente e, assim, é involuntária. Se para Freud, o inconsciente é o lugar do Outro, para Lacan, "o inconsciente é o discurso do Outro" (FINK, 1998, p.20).

Já durante a gravidez, a criança está determinada pelo universo linguístico dos seus pais. O modo como a definem, como a qualificam foi impresso pela tradição linguística. Ao nascer, a criança usa o choro como forma de se comunicar com os que cuidam dela, tentando exprimir dor, fome, ou qualquer outro sentimento de desconforto. Isso porque ela ainda não sabe falar. Seus pais, ou os que cuidam dela, tentam compreender o que seus choros significam; nomeiam, portanto, a dor, conforme seus próprios desejos. O sentido do choro passa então a ser aquele que os que cuidam da criança dão. É assim que Fink (1998, p. 23) defende que "respondendo constantemente aos gritos do bebê com comida pode-se transformar todos os seus desconfortos, o frio, a dor, em fome".

A criança precisa aprender a falar para se comunicar com as outras pessoas e comunicar o que sente e o que deseja. Só que no momento em que isso acontece, seus desejos já foram "moldados na fôrma da língua ou línguas que aprendem" (FINK, 1998, p.22). Desta forma, o desejo das outras pessoas passa a fazer parte do inconsciente dos sujeitos, tornando o inconsciente estranho e inassimilável; portanto, um Outro que não é o sujeito. E, por isso, aquilo que o sujeito pensa ser seu desejo nada mais é do que o desejo dos Outros que transborda em seu inconsciente pelo discurso (FINK, 1998).

Ao assujeitar-se ao Outro, ele torna-se sujeito. Desta forma, é um processo de escolha "forçada" que nos permite tornarmo-nos sujeitos: a escolha da alienação que "envolve 'o próprio' desaparecimento" (FINK, 1998, p.74). Assim, para Lacan (1999), o sujeito nada mais é do que uma representação momentânea fundada pelo Outro através do desejo e do discurso externo. É desta forma que Lacan afirma que o inconsciente é estruturado como uma linguagem, pois é ela (a linguagem) que o constitui (o inconsciente) (FINK, 1998). Se não fosse a linguagem, o desejo e o discurso do Outro não fluiria para dentro do sujeito comandando sua transformação. 
Portanto, a partir do que foi discutido neste item, tomamos identidade como construída e reconstruída dentro do espaço social a partir do desejo do Outro que, ao ser reconhecido pelo indivíduo como legítimo, internaliza suas práticas, ações e visão de mundo e, portanto, seu habitus. Desta forma, a identidade não é consciente e não pode, portanto, ser caracterizada como aquilo que o sujeito pensa sobre si mesmo, pois neste caso ela não exprime sua identidade, mas somente um discurso intencional.

Assim, a construção desse conceito de identidade a partir da teoria sociológica de Bourdieu e psicanalítica de Lacan está justamente na tentativa de não reduzir a sua natural complexidade. Para falar sobre a complexidade do tema identidade, fomos levadas a discutir esse conceito sob a lente de diferentes teorias até mesmo por aquelas que não discutem diretamente sobre identidade - uma vez que não conseguiríamos interpretar o fenômeno pesquisado sem ampliar o nosso olhar. Foi necessário fazer uma bricolage teórica, a fim de abrir o material coletado para a riqueza de interpretações que ele possibilitou. Bricolage, segundo Kincheloe (2001), é o uso de teorias e metodologias múltiplas, usando a interdisciplinaridade para melhor entender o que se está pesquisando.

Bourdieu (2004b, p.41), aliás, nos dá aval a essa bricolage ao negar sua classificação em uma determinada escola de pensamento:

De todo modo, a resposta à pergunta de saber se um autor é marxista, durkheimiano ou weberiano não acrescenta praticamente nenhuma informação sobre esse autor. Acho inclusive que um dos obstáculos ao progresso da pesquisa é esse funcionamento classificatório do pensamento acadêmico - e político -, que muitas vezes embaraça a invenção intelectual, impedindo a superação de falsas antinomias e de falsas divisões. [...] De minha parte, mantenho com os autores uma relação muito pragmática: recorro a eles como "companheiros", no sentido da tradição artesanal, como alguém a quem se pode pedir uma mão nas situações difíceis.

Neste caso, recorremos a Lacan $(1999 ; 2009)$ para tentar compreender como o habitus em um determinado campo se insere no indivíduo, definindo suas práticas e modo de ver o mundo. Entendemos que Lacan (1999; 2009), ao discorrer sobre o sujeito como desejo do Outro, auxilia-nos na compreensão do processo inconsciente de reconhecimento e internalização das relações sociais, base da teoria de habitus e de campo de Bourdieu (2004a; 2004b; 2003a; 2003b; 1996a; 1996b).

\section{Usinas Hidrelétricas Modificando Identidades}

Gerar energia elétrica no Brasil sempre foi sinônimo de hidroeletricidade e construção de grandes usinas. Um assunto polêmico, que nos últimos anos tem merecido grandiosas e ardentes discussões. Por um lado há aqueles que defendem a construção de hidrelétricas, reforçando basicamente a necessidade crescente de energia elétrica do país e as características positivas da hidroeletricidade. O discurso de que as hidrelétricas são uma fonte de energia limpa, por exemplo, é constantemente utilizado.

Em uma experiência didática no curso de Licenciatura de Campo da Faculdade de Educação da Universidade Federal de Minas Gerais, em que os aspectos positivos e negativos da construção da Hidrelétrica de Belo Monte, no Pará, foram discutidos pelos alunos, é possível verificar que o grupo escolhido para defender a instalação da usina se baseou no discurso da autoridade científica e na dessubjetivação dos sujeitos que serão diretamente afetados (CREPALDE, VALADARES e AGUIAR JUNIOR, 2012). Para tanto, apresentam dados técnicos que mostram que o empreendimento trará aumento dos empregos na região e, portanto, irá impactar positivamente sobre o desenvolvimento local, além de ser a melhor alternativa ao país por ser um tipo de energia com baixos custos de produção e menos poluente do que o carvão. Os ribeirinhos, neste caso, são tratados como dados, parte dos aspectos gerais.

Não por acaso, esse discurso também é uma das ferramentas utilizada pelos donos das usinas hidrelétricas para aprovar sua construção mais rapidamente. Para tanto, eles tentam trazer a população para o seu lado, 
através de campanhas publicitárias que prometem o desenvolvimento, identificando-a com a chegada dos empregos e melhoria dos serviços públicos (saúde, educação, saneamento básico, transporte, entre outros), lembra Parmigiani (2006).

Apesar disso, há vozes dissonantes e ruidosas que desmitificam as grandes usinas hidrelétricas. Esse grupo mostra que, embora utilize recursos renováveis, as usinas hidrelétricas promovem diversos outros impactos socioambientais, como assoreamento dos rios, alterações na qualidade da água, redução da pesca, o desaparecimento da fauna e da flora nativas, perdas do patrimônio cultural de diversas comunidades, mudanças significativas na geografia do território atingido, além do alagamento de grande quantidade de terras, o que representa o deslocamento compulsório de diversas famílias (REIS, FADIGAS e CARVALHO, 2005).

O impacto negativo exercido pelas usinas sobre a população ribeirinha, aliás, é o principal argumento contrário à construção de usinas hidrelétricas. Em todo mundo, de acordo com a Comissão Mundial de Barragens (CMB, 2000), "entre 40 e 80 milhões de pessoas foram fisicamente deslocadas por barragens". No Brasil, segundo Zhouri e Oliveira (2007, p.121), este número é de mais de um milhão de pessoas, tendo sido inundados "[...] 3,4 milhões de hectares de terras produtivas". Grande parte dessas pessoas foi forçada a sair de suas propriedades negociando a contragosto com os donos das usinas. O deslocamento compulsório, segundo Soares, Froehlich e Marques (2007, p. 4), traz “[...] uma sensação de impotência frente a processos cujas causas e razões poucas vezes são compreensíveis para a população e que por ela são percebidas como arbitrárias".

A Comissão Mundial de Barragens verificou que não há nos projetos de construção de usinas hidrelétricas compromisso para se lidar com os deslocamentos dos ribeirinhos e, muito menos, habilidade para isso (CMB, 2000). É comum relato de processos traumáticos envolvendo o deslocamento de ribeirinhos, devido à dificuldade de "adaptação em uma nova atividade econômica, um novo tipo de solo (sem contar as dificuldades inerentes à recuperação de benfeitorias perdidas com a mudança)" (REBOUÇAS, 2000a, p.155). Até mesmo o local escolhido para o assentamento dos ribeirinhos e o projeto de distribuição dos lotes são considerados inconsistentes com o modo de vida destas pessoas.

Rebouças (2000a; 2000b), que em seu estudo buscou entender o choque cultural enfrentado pelos ribeirinhos reassentados após a construção de hidrelétricas sob direção da Companhia Energética de São Paulo (CESP) na região do Pontal do Paranapanema, exprime a insatisfação dos assentados quanto ao modo como os lotes foram distribuídos - através de sorteio - e com relação ao projeto dos assentamentos - na forma de agrovila. O sorteio para a distribuição dos lotes separou aqueles que tinham mais relações, não garantindo "a permanência das redes de afinidades e parentesco"; e as agrovilas separaram o local de trabalho e o da morada, o que não era comum para aquelas pessoas, pois para elas somente quem mora na cidade sai de casa para ir ao trabalho (REBOUÇAS, 2000a, p.160). A proximidade entre as casas era vista também pelos moradores como uma característica da agrovila que impedia a criação de animais, aumentando seu custo de vida, pois tinham que comprar no mercado da cidade o leite e a carne, que tinham antes no seu próprio quintal. Os assentamentos, na maioria das vezes, são distantes do território original e, principalmente, do rio, fonte cultural de identidade e de subsistência. Segundo Rebouças (2000a, p.159), "a vida na barranca do rio e ao longo de seu leito pode parecer permeada de um relativo isolamento quando na verdade está engendrada numa trama complexa de relações sociais que dão sentido a um determinado modo de existência".

Os atingidos pela construção da Itaipu, no Paraná, foram "induzidos a comprar lotes de empresas de colonização" e os de Sobradinho, na Serra do Ramalho, na Bahia, "foram levados para áreas de colonização oficial”, ambos deslocados a grandes distâncias (SEVÁ, 2008, p.47). Estrela (2006) lembra que muitos dos deslocados de Sobradinho não se ajustaram à vida longe do rio, venderam seus lotes no assentamento a preços simbólicos ou os abandonaram, e voltaram para a região de onde foram retirados ou se mudaram para São Paulo. Aqueles que voltaram a viver nas margens do rio buscaram reconstruir suas vidas, mas nunca conseguiram ter as mesmas condições de antes da construção da usina. Devido ao tamanho dos lotes, a agricultura não está mais sendo praticada, e a pesca se tornou inviável, pois houve queda na produção. 
Assim, aos ribeirinhos, resta o consolo de viver perto do reservatório onde, segundo eles, as condições são superiores “[...] à vida 'cativa' dos colonos nas catingas das agrovilas” (ESTRELA, 2006, p.18).

Aqueles que conseguiram ficar no território também viram sua vida mudar. Para compreender o poder dos empreendedores da Usina Salto Caxias, no Paraná, Karpinski (2007) buscou relatos junto à população local que se manteve no território após a construção do empreendimento. Assim, através da história de vida destes indivíduos antes, durante e depois da usina, verificou que eles foram mais do que desprovidos nos aspectos econômicos, mas principalmente foram afetados na sua subjetividade, na sua ligação com o rio e com as pessoas com quem dividiam o espaço social.

Esse processo traumático de deslocamento compulsório, segundo Soares, Froehlich e Marques (2007, p.3) promove "uma série de crises de identidade nas populações afetadas, pois as mesmas não escolheram voluntariamente essa situação", devido, em grande parte, à perda de sua rede de relações e se agrava pela perda dos recursos de subsistência. O deslocamento compulsório desarticula as redes de relações sociais dos ribeirinhos, construída pelo longo contato com os vizinhos e com os familiares:

Essas redes não só canalizam as relações de ajuda mútua, trabalhosamente construídas através do tempo pela população de menor recurso e seu desenvolvimento como um todo, como também o fluxo de informações, os quais são fundamentais para seus esquemas de sobrevivência. Desta forma, a perda da rede de relações sociais de ajuda mútua conduz a uma diminuição de produtividade na pequena propriedade agrícola, que se agrava ainda mais pela anulação de recursos a que os produtores anteriormente dispunham para a sua vida (SOARES, FROEHLICH e MARQUES, 2007, p. 4).

Ao deslocar os atingidos pelas barragens, raramente as empresas se preocupam com seus meios de subsistência. Normalmente, os programas se atêm à mudança física, esquecendo-se da recuperação econômica e social dos deslocados (CMB, 2000). Segundo Rebouças (2000a), isso traz riscos de empobrecimento, que costuma durar mais de uma geração, devido à disputa de oportunidades com os novos vizinhos. Isso ocorre, pois, após a realocação, pouco se vê de ajuda mútua, predominando a concorrência, fruto da instabilidade social no novo território.

Em todos esses estudos fica evidente o despreparo com que foram tratados os ribeirinhos durante o processo de deslocamento compulsório. Em todos esses casos, eles não foram considerados como pessoas que teriam sua vida afetada pela construção da usina, mas sim como "baixas necessárias", usando o jargão dos soldados, parte do cálculo da obra. É gritante como o modo de vida dos ribeirinhos foi desconsiderado e substituído por um modelo de vida mais moderno e ideal, não na visão deles, mas dos técnicos que cuidaram de transferi-los do local. Em nome do desenvolvimento econômico, como resultado do processo traumático por qual passaram, vidas foram modificadas. Muitos dos que foram compulsoriamente deslocados sofreram um processo de empobrecimento, causado pela dificuldade de adaptação às novas condições objetivas de vida, ao mesmo tempo em que perderam referências à sua identidade. Mesmo aqueles que conseguiram se manter no território sofreram alterações nas suas vidas e, consequentemente, nas suas identidades. A desestruturação social provocada pela modificação geográfica do território separou parentes e amigos, quebrando suas redes de relações. Ao mesmo tempo, as grandes usinas hidrelétricas modificaram as características e tamanho de suas terras e do rio, colocando os ribeirinhos frente a novas condições objetivas de vida.

\section{Percurso Metodológico}

Para entendermos um pouco mais a respeito de quem era o povo que habitava a região onde foi instalada a Usina Hidrelétrica Salto Santiago, buscamos publicações - jornais, documentos, artigos, livros e teses - que nos mostrassem a história da região, da instalação da Usina e um pouco do perfil identitário e cultural dos que ali habitavam. 
As fontes documentais, em nenhum momento, serviram para checar se as informações obtidas junto aos ribeirinhos estavam ou não corretas, principalmente porque já pressupúnhamos, como diz Gadamer (2008, p. 390), que o que é dito pelos entrevistados "é uma verdade perfeita". O uso de fontes documentais serviu de auxílio à interpretação do que foi dito pelos entrevistados, buscando as forças que participaram no desenrolar do fenômeno (TRIVIÑOS, 1987) e também para descrever os discursos formalizados sobre a questão estudada.

Sabemos, no entanto, que a reconstrução da história "não passa de um exercício de transmissão de um sentido morto" (GADAMER, 2008, p. 234) se não conseguirmos enxergar que a tradição e a herança histórica têm o poder de determinar a ação e o comportamento humano. Gadamer (2008, p. 372) escreve que "os costumes são adotados livremente, mas não são criados nem fundados em sua validade por um livre discernimento". Assim, buscamos nas diferentes vozes "nas quais ressoa o passado [...] a tradição na qual participamos e queremos participar" (GADAMER, 2008, p. 377). Para Gadamer (2008, p. 386), a história é a mediação da tradição, e, se quisermos compreender o que diz o outro, devemos nos deslocar "para a perspectiva na qual o outro conquistou sua própria opinião".

Os ribeirinhos entrevistados, por meio de entrevista semiestruturada, no total de sete, foram deslocados quando da construção da Usina, mas ficaram na mesma localidade, muito perto, portanto, das suas antigas propriedades. O que ocorreu é que o rio inundou parte de suas terras e, assim, as suas moradias, os animais e a plantação tiveram que ser transferidos para uma parte da propriedade que não era antes utilizada. Também entrevistamos os representantes de algumas das organizações que atuam na região, como o do Movimento dos Atingidos por Barragens (MAB), do Instituto Paranaense de Assistência Técnica e Extensão Rural (EMATER), da Secretaria da Agricultura e do Abastecimento do Paraná (SEAB), do Instituto Agronômico do Paraná (IAPAR) e também o prefeito de uma das cidades atingidas pela construção da Usina.

Tanto para os ribeirinhos quanto para os representantes das organizações instaladas no território, aplicamos a entrevista semiestruturada e as técnicas da história oral. A história oral, segundo Alberti (2008, p.23), “[...] privilegia a recuperação do vivido conforme concebido por quem viveu". E o que o sujeito viveu está relacionado à memória individual e coletiva. De acordo com Halbwachs (2006), a memória é individual, no entanto, deve também ser entendida como um fenômeno coletivo.

No nosso caso, utilizamos história oral temática com os representantes das organizações. O que nos interessava compreender, com eles, era a história da instalação da Usina, seus impactos na região e a atuação das organizações que eles representam junto aos ribeirinhos. Não havia, portanto, nenhuma necessidade de se conhecer suas histórias de vida.

Em contrapartida, era necessário compreender o universo dos ribeirinhos antes e depois da instalação da Usina naquele espaço. Sendo assim, a história oral de vida tornou-se a melhor opção nesta fase da investigação. Desta forma, ao fazer os ribeirinhos contarem sobre suas vidas, procuramos nas suas falas o que faz sentido para eles, para que seus relatos sejam vistos como o encontro entre a sua subjetividade e a história social e cultural mais ampla.

É importante destacar que os ribeirinhos são pessoas muito desconfiadas, principalmente por estarem em uma região ainda em conflito com o empreendedor da Usina. Devido a isso, achamos melhor ir até o local manter um primeiro contato com uma das lideranças na região antes mesmo de iniciarmos a coleta dos dados. A ideia principal era encontrar indicações de supostos sujeitos para participar da pesquisa. Fomos, então, recebidos pelo prefeito de uma das cidades vizinhas à Usina, que, inicialmente nos recebeu com bastante desconfiança. Como existe um conflito entre os empreendedores da Usina e os ribeirinhos com relação à obrigatoriedade de se manter reserva legal nas margens do reservatório - os ribeirinhos alegam que esta é uma obrigação da Usina; a concessionária que administra a Usina diz que é dos ribeirinhos -, o levantamento de qualquer questão relativa aos ribeirinhos desperta desconfianças.

Esse primeiro contato, portanto, foi muito importante para que nossa pesquisa tivesse êxito, pois foi assim que conseguimos ganhar a confiança do prefeito, que nos proporcionou o contato com algumas pessoas no 
território. A partir dele tivemos acesso ao coordenador do MAB na região e conseguimos acesso a alguns ribeirinhos. No entanto, não ficamos restritos aos sujeitos indicados pelo prefeito, mas, ao adentrarmos no campo, fomos entrevistar sempre o vizinho da propriedade indicada. Isso porque sentimos que, se ficássemos presos aos sujeitos indicados pelo prefeito, teríamos a visão de um só grupo. Em apenas um caso não foi possível entrevistar o vizinho da propriedade indicada, pois ele não estava em casa.

Após a coleta dos dados, utilizamos as regras da hermenêutica filosófica de Gadamer (2008) para interpretar o material que tínhamos em mãos. Gadamer (2008, p. 385) afirma que esta totalidade pode ser conseguida usando-se a "regra hermenêutica segundo a qual é preciso compreender o todo a partir do individual e o individual a partir do todo". Desta forma, a interpretação subjaz uma relação circular, ou seja, é preciso enxergar o fenômeno de forma que aquilo que é dito pelas pessoas individualmente são ditas a partir do todo (GADAMER, 2008).

A compreensão só pode se dar pelo movimento de ir e vir do todo para a parte e vice-versa, ampliando-se "a unidade de sentido compreendido em círculos concêntricos" (GADAMER, 2008, p.386). No entanto, "a descrição heideggeriana desse círculo mostra que a compreensão do texto se encontra constantemente determinada pelo movimento de concepção prévia da pré-compreensão" (GADAMER, 2008, p.388). A compreensão, portanto, é, segundo Gadamer (2008, p.388), "o intercâmbio entre o movimento da tradição e o movimento do intérprete".

O pesquisador que busca a interpretação se apoia na tradição, nas ideias, nos valores que estão nele mesmo. Gadamer (2008, p.389) esclarece dizendo que "nós compreendemos os textos, transmitidos sobre a base de expectativas de sentido que extraímos de nossa própria relação precedente com o assunto". Segundo Rey (2002, p. 38), "o sujeito é histórico, uma vez que sua constituição subjetiva atual representa a síntese subjetivada de sua história pessoal, e é social, porque sua vida se desenvolveu na sociedade, e nela produz novos sentidos e significações que, ao constituir-se subjetivamente, se convertem em constituintes de novos monumentos de seu desenvolvimento subjetivo".

Desta forma, a compreensão hermenêutica se dá entre a estranheza e a familiaridade com o assunto, conforme a herança histórica e tradição de cada um. Por isso, é importante ter um encontro com nossa própria tradição, enxergando daí nossos próprios preconceitos, todos os juízos já construídos, "distinguindo os verdadeiros preconceitos, sob os quais compreendemos, dos falsos preconceitos que produzem os malentendidos" (GADAMER, 2008, p. 395, grifo do autor).

Só de manter uma distância temporal, conseguimos suspender nossos preconceitos. Assim, a distância histórica pode nos mostrar o verdadeiro sentido de algo, insiste Gadamer (2008). Na sua concepção, "o tempo já não é, primariamente, um abismo a ser transposto porque separa e distancia, mas é, na verdade, o fundamento que sustenta o acontecer, onde a atualidade finca suas raízes" (GADAMER, 2008, p.393).

Isso não significa, entretanto, que, ao suspender seu próprio preconceito, o pesquisador o deixará de lado "e que o outro ou o diferente venha a substituí-lo imediatamente em sua validez" (GADAMER, 2008, p. 396). Isso, segundo Gadamer (2008), seria ingenuidade. Mas é somente reconhecendo nossos próprios preconceitos que conseguiremos compreender a verdade do outro. Ao nos deslocarmos de nosso horizonte histórico para o do outro, transportar-nos-emos para a situação vivida pelo outro, poderemos compreendê-lo, pois neste momento nos tornaremos "conscientes da alteridade e até da individualidade irredutível do outro precisamente por nos deslocarmos à sua situação" (GADAMER, 2008, p. 403).

Gadamer (2007, p. 16) faz questão de deixar claro que esta distância não é só a histórica, que tem a função hermenêutica de "superar conotações falsas e aplicações destrutivas". É, portanto, mais prudente falar de uma forma geral de distância. Desta forma, para suspender os preconceitos, é necessário, também, perguntar o que o outro quer dizer. Para Gadamer (2008, p.396), "a essência da pergunta é abrir e manter abertas possibilidades". É através das perguntas que o intérprete abre "possibilidades de sentido, e com isso aquilo que possui sentido passa para a opinião pessoal” (GADAMER, 2008, p. 489). Só compreendemos aquilo que 
perguntamos. É o que buscamos fazer, nesta pesquisa: interpretar perguntando ao outro, e também, a nós mesmas. O próximo item mostra, assim, como foi essa trajetória.

\section{Os Ribeirinhos Antes e Após a Construção da Usina Hidrelétrica Salto Santiago}

A construção da Usina Hidrelétrica Salto Santiago começou no início da década de 1970, nos arredores da cidade de Laranjeiras do Sul, no Paraná. Sua construção foi promovida pelas Centrais Elétricas do Sul do Brasil S/A (ELETROSUL), seguindo diretrizes do governo militar. Perto da construção da barragem foi construída uma vila para abrigar os empregados que vinham de fora, uma cidade-acampamento, onde todas as instalações foram projetadas para serem desmontadas e removidas do local no final da obra (LOPES, 2002).

A grande empolgação dos moradores da região, principalmente os da cidade, quando do anúncio de que ali seria construída uma grande usina hidrelétrica, foi a perspectiva de que ela traria emprego e desenvolvimento. Afinal, "Laranjeiras era uma cidade perdida no mundo e pra cá vieram engenheiros, professores, tinha toda uma estrutura da ELETROSUL e das empreiteiras que serviu para o desenvolvimento", lembra Fábio $^{3}$, engenheiro agrônomo da EMATER, que mora desde pequeno na região.

Enquanto a obra estava em andamento, a maioria dos habitantes do local sentiu mesmo que o progresso estava chegando. Como costuma acontecer em locais de grandes obras, o acúmulo de novos moradores na região alimentava os negócios locais. A grande quantidade de pessoas atraídas para o local deu vivacidade ao comércio de Laranjeiras do Sul, a maior cidade nos arredores, atraindo, portanto, novos empreendimentos, de mercados a casas de prostituição. Além do mais, a própria obra empregou muita gente da região. O senhor Pedro, que na época morava em um sítio às margens do rio Cavernoso, viu muitos parentes e vizinhos irem trabalhar na obra. Segundo ele, "grande parte das famílias teve membros que foram trabalhar nesse processo". Para a empresa, contratar pessoas da região poderia ajudar na sua aceitação e na redução de possibilidades de conflitos.

No entanto, após uma década de grande movimento na região, que resultou em um comércio vibrante, a obra terminou. O que restou foi um território, geograficamente, bastante modificado pelo reservatório da Usina. Quando finalizado, o reservatório da Usina Salto Santiago ocupou $208 \mathrm{Km}^{2}$, segundo dados da empresa Tractebel Energia (2009). Isso significou o alagamento de uma grande quantidade de terras produtivas nas margens dos rios Iguaçu, Cavernoso e de outros rios do local. Desta forma, muitos ribeirinhos perderam parte ou toda sua propriedade.

Aqueles que não foram deslocados para fora do território foram empurrados para a parte montanhosa, onde o solo é pedregoso. Antes, suas propriedades ficavam numa parte plana e fértil da região, entre as margens do rio e as montanhas. Agora, além de terem suas propriedades reduzidas no tamanho, veem-se frente a condições de solo bastante diversas daquelas a que estavam acostumados. O ribeirinho, então, não sabe como agir diante das diferentes transformações no seu espaço e na sua própria identidade.

\section{Quem são (ou foram) os ribeirinhos?}

Os ribeirinhos que ainda hoje moram às margens do Rio Cavernoso são, na sua maioria, descendentes dos primeiros habitantes não índios da região, os caboclos. Sua presença no território data do final do século XIX, quando procedentes de outras regiões do Paraná e de São Paulo, embrenharam-se nas matas em busca de terras devolutas. Ali foram se estabelecendo, seguindo o curso dos rios, praticando a lavoura de

${ }^{3}$ Os nomes aqui utilizados são fictícios. 
subsistência, colhendo erva-mate e criando porcos soltos no mato. Diferentemente dos colonos sulistas - que começaram a chegar à região em grande número em meados da década de 1950 -, os caboclos plantavam principalmente para o consumo familiar.

Antes da chegada dos colonos, o modo de vida dos caboclos era reconhecido entre eles como a forma legítima de viver. Dava prestígio entre eles colher erva-mate e vender para os exploradores argentinos e gaúchos. Eram respeitados por eles. A posse da terra já era um diferencial que os colocava em uma classe superior frente àqueles que nem isso tinham, que vagavam pela região prestando serviço um dia em um lugar, no outro dia no outro. O caboclo detinha, naquele momento, o poder simbólico que regia o campo. No caso dos caboclos, trata-se de um poder construído à base do poder econômico. Mesmo que não fossem ricos, os caboclos eram os poucos que naquela região tinham onde morar e conseguiam sobreviver daquilo que plantavam e coletavam ou dos animais que criavam. Para Bourdieu (2004b), a acumulação de capital simbólico está imbricada na reputação e no prestígio. Não que o capital econômico lhes permitisse ter o poder por si só. Mas o capital econômico, consubstanciado na posse da terra, permitiu a legitimação das suas práticas e, por fim, o acúmulo de capital simbólico. A posse da terra, portanto, era o signo que os distinguia dos outros.

Mas, para os colonos sulistas - imigrantes ou filhos de imigrantes europeus -, que, naquele momento, usavam técnicas mais modernas de cultivo e criação de animais, o caboclo era considerado primitivo. Criar porcos soltos no mato, colher erva-mate no inverno e plantar somente o necessário para a sua sobrevivência significava para o colono que o caboclo não tinha propensão para o trabalho.

Enquanto os colonos se esforçavam para produzir excedentes de produção, os caboclos tinham outra lógica econômica e social. Eles queriam sobreviver. Isso parece tê-los impedido de agir igual ao colono quando se fala do uso da terra. Um dos entrevistados, o senhor Fabiano, lembra que seu avô recebia em suas terras qualquer conhecido. "Meu avô adotava todo mundo [risos]", diz senhor Fabiano. As pessoas iam chegando e podiam ficar. Enquanto tivesse espaço, ele ia cedendo lugar para mais famílias. Mesmo quando grande parte das terras do seu avô foi inundada pelas águas do reservatório, ele não permitiu que ninguém fosse retirado dali. O senhor Fabiano lembra que "quem morava lá em cima - [na parte que não foi inundada] - saiu se quis, né"?. Este tipo de atitude é incompatível com aquele que quer explorar a terra, visto que cada nova família que chegava reduziria a quantidade de terras para plantar. Numa propriedade coletiva, as pessoas consomem ali mesmo o que plantam, e dificilmente sobra alguma coisa para ser comercializada.

Entre os sujeitos desta pesquisa, encontramos o senhor Horácio, neto de colonos de origem polonesa que vieram do Rio Grande do Sul. Inicialmente, o avô do senhor Horácio foi tropeiro; em seguida, comerciante; depois, madeireiro; teve uma serraria e comprava porcos dos safristas - caboclos - e transportava até a cidade de Ponta Grossa. Com estas atividades, ele ganhou dinheiro suficiente para adquirir uma boa quantidade de terras no território. Era o verdadeiro "pioneiro", aquele que trouxe o desenvolvimento para a região, participando até da construção da estrada para Foz do Iguaçu. Conforme seu Horácio, "meu avô [...] começou a exploração da araucária, dos pinheiros aqui. Ele foi o primeiro madeireiro da região. [...] Então, a minha família viveu sempre da exploração da terra. Meu avô [...] participou de vários fatores do desenvolvimento".

Chama a atenção no depoimento do senhor Horácio, como ele define o modo como sua família trabalha com a terra, usando o termo exploração. Segundo o Dicionário da Língua Portuguesa, explorar significa tentativa ou ato de tirar utilidade de alguma coisa (HOUAISS, 2001), de modo que na agricultura, exploração é a tentativa de tirar proveito daquilo que a terra oferece; leva em conta uma racionalidade. Num primeiro momento, isto poderia ser só o resultado de sua formação educacional e do meio em que transita: o senhor Horácio é um médio produtor rural, como ele mesmo se nomeia - na visão dos agricultores familiares ele é um fazendeiro -, possui cento e trinta e quatro alqueires de terra, fez faculdade de agronomia e já foi

\footnotetext{
${ }^{4}$ Historicamente o colono, em qualquer parte do mundo e em qualquer época, "buscará passar aos descendentes a imagem do descobridor e do povoador" (BOSI, 2001, p.12).
} 
secretário da agricultura em Laranjeiras do Sul. No entanto, ao olharmos melhor, podemos verificar que ser um empreendedor, buscar as oportunidades onde elas se apresentam, parece ser um valor familiar que o senhor Horácio tem orgulho e que carrega até hoje. Na sua visão, seu avô se aproveitou dos ciclos econômicos para enriquecer, mas trouxe desenvolvimento para a região.

O senhor Luiz, filho de caboclos, relaciona-se com a terra de outra forma. Para ele, trabalhar com a terra é um meio de sobrevivência. É através dela que ele irá tirar o sustento para sua família, pois, em suas próprias palavras, "[...] todos poderiam sobreviver da terra, como meu avô conseguiu fazer por tantos anos. Pelo menos pra sobreviver ali, arrancando o sustento da terra, daria pra sobreviver". Ouvimos a mesma frase do senhor Fabiano, quando ele diz que aquela propriedade era o que sustentava toda a família antes do surgimento do reservatório da Usina.

A partir disto, começamos a nos indagar qual a carga do conceito histórico de exploração e de tirar o sustento da terra na fala destes ribeirinhos e quais os significados disto na identidade deles. Levamos em conta aqui que o habitus se instala no inconsciente dos agentes e são expressos nos sentidos dada a linguagem, ou seja, as palavras escolhidas em um discurso estão inscritas na tradição do seu grupo (GOFMANN, 1999; BOURDIEU, 2004b). Desta forma, os ribeirinhos da região de Salto Santiago nasceram numa tradição, alguns na dos caboclos, outros na dos colonos, o que, até certo ponto, formou a sua identidade.

Para as famílias ribeirinhas, o local da diversão e do trabalho era no espaço onde viviam. Saía-se pouco dos limites da propriedade, raros eram aqueles que se aventuravam num passeio até a cidade mais próxima. Mas os encontros entre os ribeirinhos não se davam só nos momentos de lazer. O senhor Pedro e o senhor Francisco, outros ribeirinhos entrevistados, lembram que o relacionamento entre os vizinhos era quase de dependência mútua. Para sobreviver naquele território, seus antepassados já haviam se acostumado a trabalhar de forma coletiva com os vizinhos, plantando e colhendo em mutirões.

É no espaço social que os agentes constroem sua identidade a partir de elementos objetivos e subjetivos (BOURDIEU, 1996b). Do lado objetivo, podemos encontrar entre os ribeirinhos em estudo, antes da construção da usina, a forma como detêm a terra e as práticas para plantio, coleta e criação de animais. Como vimos, os caboclos se sentiam seguros apenas com a posse da terra, o que para os colonos seria considerada uma situação precária. Para os colonos, somente a propriedade da terra, registrada em cartório, poderia lhes dar segurança. Ao mesmo tempo, o modo de produção dos caboclos é visto pelos colonos, recém-chegados à região, como prática primitiva.

Thiry-Cherques (2006) lembra que os elementos objetivos só se tornam intelegíveis porque foram pensados a partir dos elementos subjetivos. Assim, os conceitos de sustento e exploração encontrados nos discursos dos caboclos e dos colonos podem nos dar uma pista sobre os seus elementos subjetivos. Enquanto os colonos se esforçaram para fortalecer o que significava o desenvolvimento para a região, os caboclos tinham outra lógica econômica e social. Eles, os caboclos, queriam sobreviver. Mas o que significava sobreviver? O senhor Fabiano parece esclarecer isso, quando diz que naquele tempo as pessoas não pensavam no futuro, elas viviam dia após dia. É difícil imaginar que alguém, como seu avô, possa ter saído de tão longe - ele veio do Estado de São Paulo -, enfrentado adversidades para chegar num novo território, embrenhado-se na mata, e não tenha pensado no futuro. Provavelmente, ele tenha sim. Mas o futuro se concretizou ao tomar posse de sua terra. A posse da terra já lhe bastava para seu sustento. A terra lhe garantiria o futuro, pois dali poderia tirar, para ele e para sua família, o que comer.

\section{O papel das organizações após a construção da usina}

Algum tempo após o término da obra da Usina, diferentes organizações passaram a atuar na região. Hoje, podemos identificar algumas ali presentes, como o MAB, o Movimento dos Trabalhadores Sem Terra (MST) e o próprio poder público, representado por Prefeituras, pelo EMATER e pelo IAPAR. Elas participam, com menor ou maior intensidade, da construção da identidade dos ribeirinhos. 
No caso do MAB, observamos a presença, quase que exclusivamente, de pessoas da própria região. Os membros e os coordenadores do movimento nasceram e cresceram ali. Segundo o senhor Fábio, coordenador do MAB na região, antes mesmo de a organização existir, foram as pessoas dali que não foram reconhecidas como proprietários de terras, os empregados das propriedades, os meeiros e os posseiros, que iniciaram o movimento dos excluídos por barragens. Foram aqueles que ficaram sem terra e sem emprego que começaram a se organizar e a reivindicar seus direitos. O MAB mesmo só apareceu no território nos últimos anos a fim de organizar a luta contra a determinação legal do plantio de mata ciliar5.

Isto fez com que o próprio movimento mantivesse as características culturais da região. Existem, então, descendentes de caboclos e de colonos, pequenos e grandes produtores atuando juntos no MAB. Isso porque, segundo um dos coordenadores do movimento no território, o senhor Miguel, "o papel do MAB é como articulador. $\mathrm{O}$ MAB está na luta junto com os atingidos, mas são eles que fazem o movimento todo". O $\mathrm{MAB}$ faz reuniões com os ribeirinhos, tentando mostrar as injustiças que eles sofreram há trinta anos e que podem ocorrer novamente se não receberem indenização pelos cem metros às margens do reservatório que serão utilizados para plantio de mata ciliar.

Além dessa preocupação, não pareceu, na coleta de dados, que o MAB tenha uma atuação muito intensa na região pesquisada. Ou seja, parece que o MAB só consegue a adesão dos ribeirinhos devido a uma causa: a possibilidade de perderem parte de suas terras novamente, por conta da determinação legal do plantio de mata ciliar. Se o problema for resolvido, o movimento não tem porque existir naquele território.

Por outro lado, dois dos entrevistados, pai e filho, fizeram questão de falar de outro movimento - e de manter uma bandeira pendurada na parede atrás do fogão à lenha - o MST. Felipe, o filho, foi quem começou a falar sobre o MST, dizendo: "eu fiquei acampado em torno de quatro anos no MST, fiquei aguardando um lote pra ver se dá certo [...]. Mas é uma coisa que não é tão fácil assim”. Sua irmã foi a primeira da família a ir para um acampamento do MST. Ele um dia foi visitá-la, gostou do que viu e resolveu ficar.

Quando foi para o acampamento, Felipe não tinha terminado nem o ensino fundamental. No MST, Felipe vê uma oportunidade de voltar a estudar numa escola do movimento instalada no acampamento no município de Cantagalo. Segundo Felipe, isto mudou sua vida porque "foi lá que eu comecei a entender um pouco o processo, o que acontecia, os problemas que a gente estava enfrentando, porque nós não conseguíamos desenvolver, porque não conseguíamos vender bem o produto. Aí eu fui entendendo o processo, a conjuntura do país, o que aconteceu e o que está acontecendo. [...] Hoje eu sou outro. Tem um tio meu que diz: 'olha, o Felipe mudou'" (Felipe, ribeirinho).

Mas, mudou como? Perguntado sobre isso, Felipe responde: "Por exemplo, cultura, música. Pra mim qualquer música estava bom. Hoje, eu só escuto música gaúcha boa. [...] Ouço MPB também. Isso já foi uma mudança. [...] E aí eu consegui me valorizar do jeito que eu sou. [...] Eu não me rebaixo pra eles" (Felipe, ribeirinho).

Neste trecho, Felipe afirma que agora "consegue se valorizar do jeito que é". Não abaixa mais a cabeça para ninguém. Será? Ou será que ele está tentando nos passar um modelo em que ele acredita ser melhor? Desde os trabalhos de Freud, sabemos que o sujeito não tem plena consciência de si mesmo, pois está dividido entre o consciente e o inconsciente. Há, portanto, uma parte que o próprio sujeito não tem acesso sobre si, porque está no inconsciente. Segundo Lacan (1999), o inconsciente, "a fala do Outro", está sempre comandando suas ações. Para Lacan (1999), quando a pessoa diz "eu sou assim...", ele está racionalizando. E, ao racionalizar, usar a consciência, não é sujeito que se apresenta, mas sim um falso-ser. Segundo Fink (1998),

${ }^{5}$ Consta na Lei 4.771 de 15/09/1965, Código Florestal, alterada pela Lei 7.803 de 18/07/1989, a obrigatoriedade de se manter 100 metros de áreas de preservação permanente ao longo dos rios ou qualquer outro curso d'água compreendido entre 200 e 600 metros de largura (BRASIL, 1965). Desde 2000, a empresa que controla a Usina, Tractebel, vem pressionando os ribeirinhos para plantarem cem metros de árvores, como especifica a lei, em toda a extensão do reservatório. Isto porque a Usina também é responsável junto com os proprietários das terras, pelas margens do reservatório, e responde solidariamente, caso o Código Florestal não seja respeitado. 
este eu consciente tenta formar uma autoimagem ideal, "a fala do eu". A outra metade do sujeito, "a fala do Outro", está guardada no seu inconsciente e foi formada pelos discursos que o sujeito ouviu durante toda sua vida. A partir dos discursos internalizados é que se forma a imagem ideal que o sujeito tenta demonstrar ser. É impossível, então, acreditar que o sujeito é tudo aquilo que ele diz ser.

Ao viver e estudar no acampamento, Felipe criou um novo modelo de homem, conforme os valores difundidos pelos membros do MST. Os outros vários discursos gravados no inconsciente de Felipe podem ser até contraditórios em relação ao eu-ideal que ele usa para se descrever. Assim, por mais que Felipe pense que agora não está mais alienado, pois hoje ele não vive mais o mundo que os outros lhe passaram, sabemos que isso é impossível. Para Lacan (1999), estamos sempre alienados pelo significado que o Outro nos impõe. Quando Felipe diz que antes ouvia qualquer tipo de música e hoje ele ouve música de qualidade, queremos indagar: de quem é este padrão musical? É do Felipe? É da família do Felipe? Parece-nos que este padrão é estabelecido pelos membros do MST.

Desta forma, por mais que Felipe pense o contrário, continua sendo assujeitado. Agora, não mais por aqueles que controlam o território, como os donos da Usina ou os fazendeiros, mas pelo movimento do qual participa, o MST. E não poderia ser de outro jeito, porque uma organização só consegue reproduzir suas práticas e valores quando consegue dominar as pessoas, contando com sua cumplicidade. Trata-se do poder simbólico, que Bourdieu (2004a) conceitua como sendo um poder invisível que opera sem ser notado, mas que conta com a cumplicidade dos que a ele estão sujeitos, aumentando sua legitimidade.

Seu pai, o senhor Francisco, nunca ficou acampado, mas passou um tempo junto com os filhos no MST, ajudando a montar os grupos e a armar barracas, que servem de moradia aos agricultores sem terra. O senhor Francisco, como o filho, aprendeu no MST que é o sistema capitalista o responsável pela atual situação em que se encontram os pequenos agricultores. Ele, como seu filho, agora consegue enxergar melhor as coisas, conforme eles mesmos afirmam. Foi depois do MST que começaram a enxergar que o grande problema dos pequenos agricultores é que muitos não se unem com os iguais, preferindo se identificar com os fazendeiros/colonos.

Segundo o senhor Francisco, muitos pequenos agricultores da região só querem trabalhar com produtos que lhes deem status de rico, mesmo que não sirvam nem para sua própria alimentação. Muitos plantam fumo, por exemplo, só porque trabalham para a Souza Cruz. O problema, na visão do senhor Francisco, é que o povo está submetido a uma educação que cuida de espalhar a ideologia capitalista para todos. A escola educa para o sistema, e a família continua reproduzindo as práticas do modelo econômico vigente.

A nosso ver, a explicação pode ir além disso. Segundo Bourdieu (2004b), os dominantes são reconhecidos tanto por seus pares quanto pelos dominados por meio das marcas distintivas. Ser um pequeno produtor rural pode significar estar inserido em uma "segunda classe" de pessoas; já, o ser fazendeiro situa-se numa categoria superior, onde estão as pessoas de prestígio. É claro que o senhor Francisco tem razão quando, na sua explicação, põe a culpa na educação formal e familiar. Tanto a escola quanto as famílias estão inseridas no mesmo espaço social e, portanto, submetidas ao capital simbólico do dominante. No entanto, ao contrário do que pensa o senhor Francisco, isso não é consciente. Não se tratam de estratégias intencionais e conscientes e sim da apreensão do sentido do jogo a partir das afinidades de habitus (BOURDIEU, 2004b).

Para que isso aconteça, há de existir afinidades de habitus entre esses pequenos produtores sobre quem o senhor Francisco fala e os fazendeiros. Mas como, se eles vivem em mundos aparentemente tão diferentes? Inconscientemente, quando deseja ser uma pessoa melhor (o eu-ideal de Lacan), o melhor se equipara, para alguns, a ser fazendeiro, mesmo que as suas condições objetivas não permitam. É o discurso do Outro que se insere no inconsciente dos sujeitos, fazendo-o desejar ser um outro sujeito, o eu-ideal, como afirma Lacan (1999). Para se tornar sujeito, o pequeno produtor se sujeita ao estilo de vida do fazendeiro, conforme os moldes da escolha forçada de Lacan (1999). É por isso que não podemos classificar os indivíduos pela sua classe social. 
Podemos notar uma grande diferença entre o MAB e o MST que parece determinar o modo como agem sobre a identidade dos indivíduos. O MAB não tira os ribeirinhos de sua casa, como faz o MST, mantendo-os em acampamentos. Ao deixar os pequenos produtores nas suas próprias casas, eles não mantêm muito contato com os outros membros do movimento. No MST, os agricultores sem terra ficam quase 24 horas por dia juntos, pois moram um ao lado do outro. O acampamento do MST se torna quase um mundo à parte. No $\mathrm{MAB}$, não há participação efetiva de toda a família, geralmente são os homens que vão às reuniões e às manifestações. Já num acampamento do MST encontramos famílias inteiras.

No MST o reconhecimento dos semelhantes ocorre a partir da condição, igual para todos, de sem terra. A luta do MAB na região atualmente está relacionada a um objetivo: conseguir indenização pela área necessária ao plantio de mata ciliar às margens do reservatório. É por isto que neste movimento encontramos pequenos e grandes produtores rurais. O que importa é ser ribeirinho e estar correndo risco de ter parte de suas terras utilizada para o reflorestamento. Se conseguir concretizar este objetivo, provavelmente o movimento não conseguirá manter a união dos seus membros, pois cada um continuará tocando suas vidas.

Enquanto nos acampamentos do MST há toda uma estrutura que permite que ali haja a reprodução dos símbolos e valores do movimento (basta lembrar da bandeira instalada na casa do senhor Francisco e de seu filho Felipe), sendo que as próprias escolas instaladas nos maiores acampamentos servem também para isso, no MAB isso não existe. Desta forma, as características do MAB não permitem que haja uma ligação de reconhecimento entre seus membros, permitindo que eles se separem, ou se relacionem com o movimento de forma rápida. Ou seja, em alguns momentos, principalmente quando há manifestações, as pessoas se identificam com os outros membros do MAB; quando não há qualquer manifestação ou reunião do movimento, as pessoas se esquecem de que fazem parte do mesmo grupo.

Da mesma forma que o MAB, as organizações públicas que atuam no território, como EMATER e IAPAR, aparentemente também não conseguem uma ligação forte com os ribeirinhos. Pelo menos, é o que conseguimos observar na fala daqueles que foram entrevistados para esta pesquisa. O motivo principal talvez seja porque hoje estes ribeirinhos não participam de nenhum projeto mantido pelo governo do Estado e desenvolvido por estas organizações. Mas, será que é assim mesmo?

Para responder a isso, precisamos retornar no tempo e compreender o que essas organizações governamentais simbolizam para os ribeirinhos atingidos pela construção da usina hidrelétrica. Começaremos pela EMATER, a instituição que presta assistência técnica aos pequenos agricultores há mais tempo na região.

A EMATER já funcionava no território quando começou a construção da Usina Salto Santiago. Mas, como servidores públicos - vigiados pelo Serviço Nacional de Informação (SNI) -, seus funcionários se mantiveram afastados do processo da construção da Usina. Foi somente a partir de 1982, com as eleições diretas para o governo do Estado, que a EMATER passou a dar assistência técnica aos ribeirinhos atingidos pela construção de Itaipu, Salto Santiago e Salto Osório, reassentados na região.

A ação da EMATER junto aos ribeirinhos sempre estava relacionada a uma preocupação técnica, levando até o campo as práticas agrícolas mais aceitas no mercado. Nesse sentido, o relacionamento entre técnicos da EMATER e ribeirinhos nunca passou disso. Afinal, este é, segundo o senhor Fabrício, da EMATER, o foco da instituição. A ideia sempre foi de inclusão social, de tirar os pequenos agricultores da linha de pobreza em que se encontravam. Até hoje, a inclusão social, através de práticas agrícolas mais modernas e gerenciadas, é preocupação da EMATER.

O IAPAR, diferentemente da EMATER, não possui escritório na região. A sede do IAPAR fica em Londrina, a cerca de quatrocentos quilômetros de distância. Por isso, os projetos para a região são desenvolvidos em Londrina e executados pelos técnicos da EMATER de Laranjeiras do Sul. Os pesquisadores de Londrina só fazem o acompanhamento, de tempos em tempos, dos processos e resultados. O contato com os agricultores na região é feito mesmo pelos servidores da EMATER de Laranjeiras. Desta 
forma, a presença do IAPAR na região não é quase sentida, pois os projetos que ela desenvolve são executados pelos técnicos da EMATER.

Apesar de estas organizações trabalharem em projetos com pequenos agricultores na região, de acordo com o senhor Fabrício, não há nenhum programa específico para os ribeirinhos. Ele chega a afirmar que tem "pouco conhecimento, inclusive, do movimento deles, das causas, da dedicação". Os ribeirinhos, nos projetos destas organizações, são encarados como qualquer pequeno produtor rural. Não há nenhum tratamento diferenciado.

Desta forma, entendemos que a causa da fragilidade das relações entre estas organizações públicas EMATER e IAPAR - e os ribeirinhos está, em grande parte, no não reconhecimento dos problemas enfrentados pelos ribeirinhos após a construção da Usina. Não há, sequer, um projeto que vise aproveitar os recursos do rio, como piscicultura, por exemplo. Isso não possibilita que muitos dos ribeirinhos se identifiquem com eles. Tanto EMATER quanto IAPAR, ao não manterem uma ligação com os ribeirinhos, fazem com que sejam vistas pelos ribeirinhos como organizações dos diferentes, ou seja, como os de fora.

No entanto, não há como dizer que, embora a ligação com os ribeirinhos seja fraca, muitos não tenham incorporado as práticas impostas pela EMATER e pelo IAPAR. Afinal, as práticas difundidas por essas organizações são consideradas legítimas e por isso, tendem a se espalhar pelo território. Mesmo que um ribeirinho nunca tenha sido atendido por técnicos da EMATER ou do IAPAR, as práticas destas organizações já estão difundidas no campo, tornando-se, portanto, um habitus. Uma parte da população ribeirinha percebe que hoje, para sobreviver no campo, é necessário se modernizar. E a modernização está relacionada a práticas econômicas consideradas legítimas pelo sistema.

Desta forma, os projetos criados tanto pela EMATER quanto pelo IAPAR, em muitos casos, trazem grandes modificações na prática diária dos agricultores. Existem novas tecnologias que devem ser aprendidas por aqueles que participam dos projetos destas organizações. O modo como sempre fizeram, muitas vezes, são considerados inadequados, visto que a própria noção de desenvolvimento rural aceito como legítimo hoje, busca incutir nos pequenos agricultores práticas desenvolvidas num outro campo: o do saber técnicocientífico dentro do sistema econômico capitalista.

O senhor Fabiano (ribeirinho), por exemplo, deseja muito criar gado, uma prática que ele nunca teve, mas que é considerada hoje, naquele território, a melhor opção. Neste caso, o senhor Fabiano, mesmo inconscientemente, incorporou as disposições duradouras dominantes e passou a viver na mesma lógica deles, conforme defende Bourdieu (2004a), quando explica como se dá a socialização dos agentes. Ao incorporar estas disposições duradouras - o habitus daquele campo -, passa a aceitar as práticas modernizantes como normal. Mas, a nossa reflexão aqui esbarra numa questão: alguns dos entrevistados, não necessariamente, reproduzem esse habitus e, portanto, não utilizam as mesmas práticas.

É neste momento que os conceitos de Lacan (1999) sobre o funcionamento dos mecanismos subjetivos se tornam esclarecedores, pois é possível compreender como o habitus bourdieusiano, em forma de discurso, entra no sujeito a partir do que Lacan (1999) conceitua como "eu-ideal" e "escolha forçada". Ao compreender Lacan $(1999 ; 2009)$, temos a clara noção de que nada é automático, pois os sujeitos estão imersos nos discursos de diferentes Outros. Para Lacan (2009, p.18), "[...] há uma sociedade de senhores" aludindo à dialética do senhor e do escravo de Hegel - que, após as lutas pelo reconhecimento, irão ser importantes em um determinado território. É justamente qual Outro foi significante em dado momento e espaço? Qual Outro internalizou seus significados formando a imagem do eu-ideal para o sujeito? Para qual Outro o sujeito se assujeita para se tornar sujeito? As respostas para cada uma dessas questões, se elas forem possíveis de serem desveladas, é que irão mostrar os habitus em que os agentes estão inseridos. 


\section{Como as organizações atuaram/atuam para a (re)construção da identidade dos ribeirinhos?}

Nas margens do Rio Cavernoso, as modificações ocorridas no meio social após a construção da Usina abriram as portas para a reconstrução desse espaço. Segundo Bourdieu (2004a), poder simbólico é aquele que necessita apenas ser aceito como legítimo num determinado campo para impor ao grupo uma mesma forma de olhar o mundo. Nas margens norte dos rios que formaram o reservatório da Usina Salto Santiago, eram a pequena propriedade e a agricultura de subsistência que dominavam o território. Com o alagamento provocado pela Usina, muitos ribeirinhos se viram frente a novas condições objetivas de produção: o solo montanhoso e cheio de pedras, características essas a que eles não estavam acostumados.

Com isso, muitos pequenos produtores começaram a vender as suas propriedades para os fazendeiros pecuaristas, que, naquele momento, tinham o capital cultural e econômico mais valioso. Aos poucos, a economia de subsistência da região foi substituída pela pecuária. Os camponeses ficaram reduzidos a um pequeno número, deixando grande parte da região para o latifundiário.

Com grandes extensões de terra ocupadas por apenas um dono, as pequenas propriedades se distanciaram uma da outra. Muitos entrevistados reclamaram que hoje na região, antes bastante povoada, quase não sobrou ninguém. Se antigamente as famílias viviam muito próximas e construíram um relacionamento de dependência mútua, com a chegada dos fazendeiros esta lógica foi quebrada. Como a distância entre uma propriedade e outra ficou maior, o contato entre estas famílias ficou mais difícil.

Assim, a construção da Usina e a chegada dos fazendeiros fizeram com que houvesse uma defasagem do habitus dos ribeirinhos com relação às condições que se apresentavam. Com a diminuição da população de camponeses e a maior concentração de terras nas mãos dos fazendeiros, a cultura local se alterou. Segundo Bourdieu (2004a), um campo contempla as relações de força que determina que ganhe o jogo aquele que detém mais capital, seja ele simbólico, econômico, social ou cultural. E isso faz com que os discursos dominantes tenham mais força para prevalecer. $\mathrm{O}$ estilo de vida dos fazendeiros, alinhado à mesma lógica capitalista que regia os colonos, ganhou legitimidade, forçando os caboclos a se adaptarem. Práticas que eram consideradas importantes naquele território passaram a perder espaço para novos valores.

Ao não manterem contato uns com os outros, muitos dos costumes e valores dos camponeses começaram a se perder. Um dos pilares que sustentava a vida em comunidade naquele espaço, a ajuda mútua, foi aos poucos desmoronando. Ao perderem as práticas comunitárias e se encontrarem frente às novas condições objetivas, instaurou-se um crescente processo de empobrecimento dos ribeirinhos.

O próprio poder público ajudou na reprodução desses valores e práticas. Neste caso, a participação das organizações serve como reprodutor das práticas própria do sistema capitalista. A vida dos ribeirinhos mudou com a construção da Usina, mas não só por isso. O próprio momento político e econômico vigente no país, a partir da década de 1970, principalmente com o fortalecimento da Revolução Verde, ajudou na disseminação das práticas desenvolvimentistas e na exclusão do modo de produção tradicional, mais rústico. No entanto, a instalação da Usina Salto Santiago na região acelerou os processos de êxodo rural e concentração de terras e renda, tornando mais rápida a disseminação do discurso capitalista.

Modo de vida este, de certa forma, disseminado pela EMATER e pelo IAPAR, duas organizações públicas que trabalham com os agricultores. Apesar de no espaço em estudo, nenhuma destas organizações agirem diretamente sobre os ribeirinhos, a sua influência no meio pode ser sentida quando os agentes reproduzem suas práticas, mesmo que nunca tenham sido atendidos por elas. É que as práticas por trás do saber técnicocientífico tanto da EMATER quanto do IAPAR são consideradas dominantes dentro do sistema econômico vigente.

É certo que existem diferenças entre os sujeitos dentro do campo, pois a internalização do discurso do Outro depende do seu reconhecimento (LACAN, 1999). Se nos primeiros momentos, após o aumento das fazendas, os ribeirinhos passaram a ter que trabalhar como os colonos, um pouco mais tarde houve, entre os 
ribeirinhos, quem interpretasse essa situação de outra forma. Como viram que, mesmo tentando agir como os colonos, muitos não iam para a frente, passaram a procurar novas formas de reconhecimento.

O contato com movimentos sociais de esquerda, principalmente o MST, foi essencial para que isso ocorresse. E é por isso que nesta pesquisa encontramos o território dividido entre aqueles que se adaptaram ao habitus dominante e os que formaram uma identidade de resistência a ele, identificando-se com grupos de movimentos sociais, como o MAB e o MST. Tanto o MAB como o MST reproduzem a ideologia de esquerda, contrária aos fundamentos modernizantes da ideologia capitalista.

No entanto, é o MST que conseguiu maior reconhecimento. O MST tem uma história mais ampla que o $\mathrm{MAB}$, o que permite que seus símbolos e valores sejam reproduzidos constantemente, forçando a identificação entre os seus membros. O modo como o MST trata os pequenos proprietários de terras - como camponeses - os tornam iguais, facilitando a identificação.

Essa palavra está na fala de muitos dos ribeirinhos que entrevistamos. Um deles, o senhor Luiz, afirma já no começo de seu depoimento, que ele vem de "[...] uma família que se identifica como camponesa desde o tempo do meu avô". A palavra "camponês" simboliza para muitos um modo de vida tradicional, da forma como viviam seus pais e avós. Ao se identificarem com o MST, muitos se transferem para os acampamentos. Lá, passam a conviver com os valores do movimento, o que reforça a sua assimilação. Aqueles que estão na "luta" são vistos como iguais, pois sofreram com a perda de suas terras, mesmo que não tenha sido da mesma maneira.

Desta forma, a dinâmica do espaço social revela que na busca de reconhecimento o sujeito internaliza as práticas de um determinado habitus se assujeitando para se tornar sujeito. Para ser o sujeito do consciente, há necessidade de esconder o sujeito inconsciente, afirma Lacan (1999). Este é o caminho mais fácil, defende Fink (1998). É como se os ribeirinhos, ao mesmo tempo em que desejam a volta do estilo de vida mais rústico, praticado por seus antepassados, rebelassem-se contra a imagem de homem rústico e acomodado que eles deixaram de ser. Aqueles que se voltam para uma ideologia de esquerda estão na "luta" e não querem ser vistos como pacíficos como seus pais.

\section{Conclusão}

Nesta pesquisa ficou visível a dinâmica do movimento das organizações em busca de justificativas à própria legitimidade, sempre que as condições objetivas de um espaço mudam. Não são exatamente elas que alteram o mundo social, mas quando alguma coisa no contexto muda, elas acabam penetrando no ambiente, impondo aos agentes suas normas, práticas e saberes. Foi o que aconteceu com os ribeirinhos da região pesquisada. Enquanto havia certa estabilidade no território, não houve espaço para a entrada de novas organizações. Os ribeirinhos viviam bem naquele lugar por anos antes da chegada da Usina. Quando a Usina se instala ali, desestabiliza o território, e as portas são abertas para que novas organizações comecem a agir.

Isso porque a instalação da Usina acarretou mudanças objetivas e subjetivas naquele espaço. Do lado objetivo, as principais mudanças estão relacionadas às características e ao tamanho das propriedades, que além de terem sido reduzidas, foram empurradas para a parte do território onde o solo é cheio de pedras e montanhoso. Características bem diferentes daquelas em que os ribeirinhos estavam acostumados. Além disso, a maior distância entre as propriedades dificultou as trocas entre os ribeirinhos, desarticulando sua rede de relações, responsável pela manutenção de suas práticas, como os mutirões e as técnicas de cultivo e criação de animais.

Do lado subjetivo, das estruturas mentais dos indivíduos naquele espaço, encontramos os elementos que possibilitam o reconhecimento inconsciente tanto entre eles, como entre eles e as organizações. É assim que a dualidade sobrevivência/exploração, técnicas primitivas/modernizantes, camponês/fazendeiro ou colono, 
encontrada no espaço em estudo, permite compreender como o discurso do Outro, a partir do eu-ideal, entrou nos sujeitos.

Bourdieu e Lacan relacionam a internalização e a reprodução das relações sociais com a busca por prestígio. O capital simbólico dará, para aqueles que o possuem, mais prestígio (BOURDIEU, 2004a). Assim, não é de se estranhar que o sujeito se assujeite ao desejo do Outro, que ele vê como eu-ideal, para se tornar sujeito (LACAN, 1999). Não queremos aqui cair na ingenuidade do dominante como usurpador e nem do dominado como usurpado. Isso porque, como Bourdieu (2004b, p.201), acreditamos que "as pessoas que atendem bem aos interesses de seus mandantes são pessoas que atendem a si mesmas ao atendê-los".

Enquanto os ribeirinhos detinham o poder simbólico na região, como resultado do prestígio adquirido pela posse da terra, seu habitus era incorporado e disseminado naquele espaço social. A partir do momento em que as condições objetivas mudam e seu estilo de vida de camponês não é mais considerado o modelo ideal, o modo de vida dos fazendeiros ganhou legitimidade, forçando os caboclos a se adequarem. Ao mesmo tempo, algumas organizações que adentraram o território, como a EMATER e o IAPAR, foram, aos poucos, ajudando a disseminar as práticas modernas de plantio, colheita e criação de animais, visto que o habitus dominante está presente nelas. Desta forma, nos primeiros momentos após a construção da Usina, muitos dos ribeirinhos buscaram se adequar ao modo de vida dos fazendeiros na busca da manutenção de seu prestígio. Mesmo inconscientemente, reconhecem os dominantes e desejam ser como eles, assujeitando-se ao estilo de vida do fazendeiro, conforme os moldes da escolha forçada de Lacan (1999).

No entanto, como diz Bourdieu (2004b), não podemos olhar o espaço social como homogêneo, pois nele subsistem agentes com diferentes modos de percepção. No espaço em estudo, alguns viram que mesmo tentando ser como os fazendeiros (ou os colonos) não conseguiam ir pra frente. Essa descoberta se deu, muito em parte, devido ao contato que alguns ribeirinhos tiveram com o MST. Por ser uma organização que vai contra os valores econômicos dominantes, o MST não pode se dar ao luxo, como faz o IAPAR e a EMATER, de ter suas práticas e ideias disseminadas sem quase nenhum esforço. Afinal, o habitus do dominante, afirma Bourdieu (2004a), resultado das lutas anteriores de representação, já está espalhado pelo espaço social impondo suas práticas e representações. Para o MST ter seu habitus internalizado e disseminado entre seus membros, precisa se empenhar em destruir a imagem do eu-ideal que domina o campo. É por isso que o MST cuida de disseminar seus ideais por meio de símbolos que identifiquem o movimento, acampamentos, escolas e, principalmente, do reconhecimento da condição de camponês sem terra.

Assim, não há como negar que a construção da Usina Hidrelétrica Salto Santiago transformou o universo simbólico dos ribeirinhos que foram por ela atingidos. Junto com isso, as organizações que ali se estabeleceram após a construção da Usina ajudaram na (re)construção de suas identidades. Ou seja, tanto aqueles que introjetaram práticas e modos de vida dos "fazendeiros" tiveram que reconstruir sua identidade, como aqueles que internalizaram a ideologia de esquerda tiveram também que fazer uma (re)construção dela.

Mas, longe de ser um mecanismo automático, a incorporação do habitus opera no inconsciente a partir do discurso e do desejo do Outro e, portanto, do reconhecimento do eu-ideal. Depende, portanto, dos mecanismos de percepção de cada um desse eu-ideal, e que este se forma a partir daquela representação que seja a legitimada para aquele indivíduo. Assim, se para um determinado indivíduo se tornar sujeito envolve, inconscientemente, assujeitar-se ao habitus dos fazendeiros/colonos, assim será feito; da mesma forma que para outros, a imagem do fazendeiro/colono não faz qualquer sentido e, para se tornar sujeito, ele irá lutar contra esse modo de vida, assujeitando-se ao modelo de camponês.

Assim, empiricamente, o artigo mostra que as diferentes organizações que rodeiam os indivíduos influenciam de formas diversas os múltiplos agentes que compõem a sociedade atual. Elas têm discursos e ideologias complexas, às vezes não tão explícitas, e jogam no campo a partir de diferentes estratégias de atuação. Esta pesquisa contribui, ao mostrar como essas estratégias podem ser sutis e passarem despercebidas a uma primeira impressão. O processo de internalização (assujeitamento) dessas estratégias e a consequente "compra" de um discurso entra nos indivíduos a partir de uma perspectiva de um eu-ideal, uma 
busca por poder e prestígio. Trabalhar com a hermenêutica de Gadamer muito nos auxiliou a chegar a essa conclusão, pois foi com um olhar para a história, a tradição e o contexto que conseguimos uma visão, ao mesmo tempo próxima e distante o suficiente para interpretarmos o que estava nos sendo apresentado.

Por fim, entender o processo de construção e reconstrução de identidades no espaço social a partir do desejo do Outro, que, ao ser reconhecido pelo indivíduo como legítimo, internaliza suas práticas, ações e visão de mundo e, portanto, seu habitus, possibilita um novo olhar sobre esse tema. Teoricamente, acreditamos que esta seja a maior contribuição do artigo: a partir de um trabalho de bricolage, em que juntamos Bourdieu e Lacan para compreendermos melhor como ocorre o processo de construção/reconstrução de identidades, conseguimos notar que os indivíduos, ao serem interpelados pelo meio (no caso, as organizações), também têm estratégias, e que essas não são necessariamente nem conscientes nem inconscientes, mas que se formam a partir do jogo em questão, em sua busca por poder simbólico. Assim, a aparente mistura epistemológica que caracterizou esta pesquisa se justifica pela nossa opção de tentar captar e ampliar as diversas nuances ontológicas do fenômeno em estudo - a identidade - e esperamos que essa ousadia acadêmica seja perdoada e ao mesmo tempo reconhecida como uma tentativa de contribuição para o campo dos estudos organizacionais.

\section{Referências}

ALBERTI, V. Manual de história oral. 3. ed. Rio de Janeiro: FGV, 2008.

BOSI, A. Dialética da colonização. 4. ed. São Paulo: Companhia das Letras, 2001.

BOURDIEU, P. Razões práticas: sobre a teoria da ação. 9. ed. Campinas: Papirus, 1996 .

1996b.

A economia das trocas linguísticas: o que falar quer dizer. São Paulo: Editora da Universidade de São Paulo,

Esboço de uma Teoria da Prática. In: ORTIZ, R. (Org.). A sociologia de Pierre Bourdieu. São Paulo: Olho d'Água, 2003a.

Gostos de classe e estilos de vida. In: ORTIZ, R. (Org.). A sociologia de Pierre Bourdieu. São Paulo: Olho d’Água, 2003b.

O poder simbólico. 7. ed. Rio de janeiro: Bertrand Brasil, 2004a.

Coisas ditas. São Paulo: Brasiliense, 2004b.

BRASIL. PRESIDÊNCIA DA REPÚBLICA. Lei $\mathbf{n}^{\mathbf{0}}$ 4.771, de 15 de setembro de 1965. Disponível em: <http://www.planalto.gov.br/ccivil_03/LEIS/L4771.htm〉. Acesso em 2 ago. 2009.

CMB - COMISSÃO MUNDIAL DE BARRAGENS. Barragens e desenvolvimento: um novo modelo para tomada de decisões: o relatório da Comissão Mundial de Barragens: sumário. 2000. Disponível em: $<$ http://www.dams.org/report/wcd_sumario.htm〉. Acesso em 15 de dezembro de 2008.

CREPALDE, R. S.; VALADARES, J.M; AGUIAR JUNIOR, O.G. Análise de uma questão socialmente controversa numa turma de licenciatura de campo: a construção da usina hidrelétrica de Belo Monte no Brasil. IN: SEMINÁRIO IBÉRICO, 7.; SEMINÁRIO IBEROAMERICANO CTS, 3., Anais Eletrônicos... 2012.

ESTRELA, E. S. Um caso de deslocamento compulsório: o projeto especial de colonização Serra do Ramalho Bahia. IN: CONGRESSO LATINO AMERICANO DE SOCIOLOGIA RURAL, Quito, Anais Eletrônicos... 2006.

FINK, B. O sujeito lacaniano. Rio de Janeiro: Jorge Zahar, 1998. 
GADAMER, H. Verdade e método II: complemento e índice. 3. ed. Petrópolis: Vozes; Bragança Paulista: Editora Universitária São Francisco, 2007. Coleção Pensamento Humano.

Verdade e método I: traços fundamentais de uma hermenêutica filosófica. 9. ed. Petrópolis: Vozes; Bragança Paulista: Editora Universitária São Francisco, 2008. Coleção Pensamento Humano.

GODOI, C. K. Psicanálise das organizações: contribuições da teoria psicanalítica aos estudos organizacionais. Itajaí: Univali, 2005

GOFFMAN, E. A representação do Eu na vida cotidiana. 8. ed. Petrópolis: Vozes, 1999.

HALBWACHS, M. A memória coletiva. São Paulo: Centauro, 2006.

HOUAISS, A. Dicionário Houaiss da língua portuguesa. Rio de Janeiro: Objetiva, 2001.

KARPINSKI, C. Sobre as águas a memória: relações de poder e subjetividade durante a implantação da Usina Hidrelétrica Salto Caxias (Paraná, 1989-2001). 2007. Dissertação (Mestrado em História) - Departamento de História, Universidade Federal de Santa Catarina, Florianópolis, 2007.

KINCHELOE, J. L. Describing the Bricolage: conceptualizing a new rigor in Qualitative Research. Qualitative Inquiry, v.7, n.6, p.679-692, 2001.

Rethinking Critical Theory and Qualitative Research. In: DENZIN, N. K.; LINCOLN, Y. S. (Editors). The Sage Handbook of Qualitative Research. 3. ed. California: Sage Publications, 2005a. $350,2005 b$

On to the next level: continuing the conceptualization of the Bricolage. Qualitative Inquiry, v.11, n.3, p.323-

LACAN, J. O seminário: livro 5: as formações do inconsciente. Rio de Janeiro: Jorge Zahar, 1999.

Seminário, livro 18: um discurso que não fosse semblante. Rio de Janeiro: Jorge Zahar, 2009.

LOPES, J. M. A. O dorso da cidade: os sem-terra e a concepção de uma outra cidade. In: SOUSA SANTOS, B. (Org.). Produzir para viver: os caminhos da produção não capitalista. São Paulo: Record, 2002.

MISOCZKY, M. C. A. Implicações do uso das formulações sobre campo de poder e ação de Bourdieu nos Estudos Organizacionais. RAC, Edição Especial, p.09-30, 2003.

PARMIGIANI, J. Apontamentos para a história de uma luta: os atingidos pela barragem de Salto Caxias/PR. Tempo da Ciência, v.26, n.13, p-107-123, $2^{\circ}$ sem. 2006.

PIMENTEL, T. D.; CARRIERI, A. P. A espacialidade na construção da identidade. Cad. Ebape.br, v.9, n.1, p.1-21, jan./mar. 2011.

REBOUÇAS, L. M. A noção de espaço nos reassentamentos planejados pela Cesp: uma análise antropológica. In: WORKSHOP BARRAGENS, DESENVOLVIMENTO E MEIO AMBIENTE, 2000, São Paulo. Anais..., São Paulo: [s.n], 2000a.

O planejado e o vivido: o reassentamento de famílias ribeirinhas no pontal do Paranapanema. São Paulo: Annablume, 2000b.

REIS, L. B.; FADIGAS, E. A.; CARVALHO, C. E. Energia, recursos naturais e a prática do desenvolvimento sustentável. Barueri: Manole, 2005.

REY, F. L. G. Pesquisa qualitativa em psicologia: caminhos e desafios. São Paulo: Thomson, 2002.

SANTOS, M. Sociedade e espaço: a formação social como teoria e como método. Boletim Paulista de Geografia, n.54, p.81-99, jun. 1977. 
SEVÁ, O. Estranhas catedrais: notas sobre o capital hidrelétrico, a natureza e a sociedade. Ciência e Cultura, São Paulo, v.60, n.3, p.44-50, set. 2008.

SOARES, N. B.; FROEHLICH, J. M.; MARQUES, M. M. S. A identidade água abaixo: os reassentados da Usina Hidrelétrica Dona Francisca (UHDF) - RS. In: SOBER - CONGRESSO DA SOCIEDADE BRASILEIRA DE ECONOMIA, ADMINISTRAÇÃO E SOCIOLOGIA RURAL, 2007, Londrina. Anais Eletrônicos... 2007.

STEINMETZ, G. Bourdieu's disavowal of Lacan: psychoanalytic theory and the concepts of "habitus" and "symbolic capital”. Constellations, v.13, n.4, p.445-464, 2006.

THIRY-CHERQUES, H. R. Pierre Bourdieu: a teoria na prática. RAP, Rio de Janeiro, n.40, v.1, p.27-55, jan./fev. 2006.

TRACTEBEL ENERGIA. Ficha Técnica: UHE Salto Santiago: Relatório Online. [S.1.; s.n.], 2009. Disponível em: <http://www.tractebelenergia.com.br/modules/system/viewPage.asp?P=827\&VID=default\&SID=921329465220996\&S $=1 \& \mathrm{C}=5775>$. Acesso em: 10 ago. 2009.

TRIVIÑOS, A. N. S. Introdução à pesquisa em ciências sociais: a pesquisa qualitativa em educação. São Paulo: Atlas, 1987.

ZHOURI, A.; OLIVEIRA, R. Desenvolvimento, conflitos sociais e violência no Brasil rural: o caso das usinas hidrelétricas. Ambiente \& Sociedade, Campinas, v.10, n.2, p.119-135, jul./dez. 2007. 